\title{
Engineering Subsoil Characterization for Shallow Foundation Design in Ode Irele Area of Ondo State, Southwestern Nigeria
}

\author{
Olumuyiwa O. Falowo and Michael B. Amodu
}

\section{ABSTRACT}

Integrated geophysical and geotechnical investigations for foundation design have proved to be good veritable tools in effective foundation design and construction. Geophysical and geotechnical methods involving electrical resistivity and cone penetration test have been carried out to investigate the foundation soil conditions of Ode Irele, southwestern Nigeria. Six vertical electrical sounding (VES) were carried out along two traverses; which is complemented by two cone penetration tests with seven trial tests at different subsurface depths. The geotechnical results showed that the soils are sand and silt dominated. All the tested parameters fall within the Nigeria federal ministry of works and housing specification with liquid limit $(<50 \%)$, plastic limit $(<30 \%)$, plasticity index $(<20 \%)$. The geoelectric sections identified maximum of six geoelectric/geologic subsurface layers comprising the topsoil (red sand), weathered layer (made up of coastal sand/white sand), clayey sand (which is the major aquitard in the area), intermediate sand aquifer unit. However the coastal sand layer has moderately high resistivity at shallow depth to sustain foundation load with thickness greater than $2 \mathrm{~m}$. The groundwater level measured from existing borehole records $17.5 \mathrm{~m}$ which may not or seriously affect the bases of the foundation footing. Consequently an average allowable bearing capacity of $150 \mathrm{KN} / \mathrm{m}^{2}$ (ultimate bearing capacity of $450 \mathrm{KN} / \mathrm{m}^{2}$ ) would be appropriate for design of shallow foundation in the area, at a depth not less than $1.6 \mathrm{~m}$ in Ode Irele and $0.8 \mathrm{~m}$ at Ajagba. The foundation width of $0.6 \mathrm{~m}$ would produce minimum bearing settlement less than $25 \mathrm{~mm}$. The appropriate (recommended) ultimate bearing and allowable bearing capacity for strip and square footings at depth levels of $0.6-1.2 \mathrm{~m}$ vary from $1486-1842 \mathrm{KN} / \mathrm{m}^{2}$ and $495-614 \mathrm{KN} / \mathrm{m}^{2}$; and $2056-2489 \mathrm{KN} / \mathrm{m}^{2}$ and $685-830 \mathrm{KN} / \mathrm{m}^{2}$ respectively.

Keywords: allowable bearing pressure, cone penetration test, friction ratio, geotechnics, strip and square foundation
Published Online: April 19,2020

ISSN: $2684-446 \mathrm{X}$

DOI : $10.24018 / 2020.1 .2 .6$

\section{O. O. Falowo*}

Department of Civil Engineering Technology, Faculty of Engineering Technology, Rufus Giwa Polytechnic, Owo, Ondo State, Nigeria.

(e-mail:

oluwanifemi.adeboye@yahoo.com)

\section{B. Amodu}

Department of Civil Engineering Technology, Faculty of Engineering Technology, Rufus Giwa Polytechnic, Owo, Ondo State, Nigeria.

(e-mail: deleamodu@gmail.com)

\section{INTRODUCTION}

Soil exploration is has become an important preconstruction investigation especially in the face of incessant structural failure in Nigeria especially building structure [1]-[2]. The extent of the exploration depends upon the magnitude and importance of the project. Projects such as buildings, power plants, fertilizer plants, bridges etc., are localized in areal extent. The area occupied by such projects may vary from a few square meters to many square kilometers. Transmission lines, railway lines, roads and other such projects extend along a narrow path. The length of such projects may be several kilometers. Each project has to be treated as per its requirements. The principle of soil exploration remains the same for all the projects but the program and methodology may vary from project to project. The elements of soil exploration depend mostly on the importance and magnitude of the project, but generally should provide the following: information to determine the type of foundation required such as a shallow or deep foundation [3]-[4] necessary information with regards to the strength and compressibility characteristics of the subsoil to allow the design engineer to make recommendations on the safe bearing pressure or pile load capacity. Soil exploration involves broadly the following [4]:

i. Planning of a program for soil exploration.

ii. Collection of disturbed and undisturbed soil or rock samples from the holes drilled in the field. The number and depths of holes depend upon the project.

iii. Conducting all the necessary in-situ tests for obtaining the strength and compressibility characteristics of the soil or rock directly or indirectly.

iv. Study of ground-water conditions and collection of water samples for chemical analysis.

v. Geophysical exploration, if required.

vi. Conducting all the necessary tests on the samples 
of soil /rock and water collected.

vii. Preparation of drawings, charts, etc.

viii. Analysis of the data collected.

ix. Preparation of report.

Cone penetrometer testing (CPT) is a fast, effective, and relatively inexpensive system for collecting important soils parameters during a geotechnical site investigation or subsoil exploration [5]. When used in conjunction with conventional drilling and sampling methods, it provides a more complete description of the subsurface conditions, thereby reducing uncertainty in design and construction. CPT methods can be divided into two basic groups: geophysical logging and stratigraphic profiling; and specific test methods. Testing equipment consists of a cone on the end of a series of rods that are pushed hydraulically into the ground. CPT logging is fast and economical, particularly in soft soils. CPTs can also provide preliminary evaluations of soil parameters and provide quantitative estimates of various geotechnical parameters based on empirical correlations. Specific tests measure soil properties at a particular point, while some in situ CPTs can characterize specific engineering properties, including shear strength and modulus of elasticity [6]-[7]. They require the use of specialized equipment, however, and can be slower and more expensive. Because of the increased cost, they are best used in critical areas that have been previously identified. CPTs can be used to screen subsurface conditions during preliminary geologic investigations and locate borings for subsequent detailed geologic investigations. Soundings can be used to pinpoint changes in the lithology (stratigraphy) and identify areas to be sampled. CPT is particularly useful in non-uniform foundations and where undisturbed samples are difficult to obtain [8].

Consequently the results of CPT can be used to make reliable estimates of settlement and undrained shear strength in areas where some basic information about the engineering properties of the soil is available [9]. Results, however, should always be confirmed or correlated with laboratory analyses of actual samples. Fewer physical samples are required if the geology of the area and some of the engineering properties of the soil are understood. While the CPT equipment cannot obtain a sample, some samplers can also be pushed into the ground using CPT equipment. Undisturbed soil sampling is vital to the success of a geotechnical investigation and should be considered a companion of CPT. CPT data complement undisturbed sampling and provide a significant volume of in situ information that is difficult to achieve in the lab. Comparing lab results of both shear and consolidation tests with CPT data reduces the uncertainty of either set of data [10].

Geophysical investigation offers a cheaper and faster means of getting detailed and credible information about the subsurface. Different geophysical techniques possess ability to image the ground in terms of soil/rock association, distribution and structural deformation, which offer credible information regarding the support in term of strength that a foundation rock is likely to offer to engineering structures [11]-[13]. Electrical Resistivity Imaging (ERI) technique has been very effective in illuminating the subsurface and apt at providing information about the rock physical properties for economic, environmental and engineering purposes [14]-
[16]. Different electrical data acquisition technique as well as electrode and profile configurations have been described to present different desirable subsurface imaging abilities [17]-[18]. Three dimensional (3D) ERI geophysical investigation approach offers ability to characterize the subsurface as well as determine heterogeneity in measured rock properties along the vertical $(\mathrm{z})$ and the two orthogonal horizontal ( $\mathrm{x} \& \mathrm{y}$ ) directions [17]. The determination of variation in foundation rock's properties along the three orthogonal directions affords the ability to evaluate the spatial variation in rock strength as imposed by the heterogeneity of rock properties as they vary from place to place [17].

\section{DESCRIPTION OF THE STUDY AREA}

The study area is Ode Irele local government of Ondo State, which falls in within southwestern Nigeria (Fig. 1). It covers an area about $300 \mathrm{~km} 2$ between 705000 and 735000 $\mathrm{mE}$ and 695000 and $735000 \mathrm{mN}$. Major part of the study area is devoted to fishing and agricultural activities. The people of the area depends on government boreholes due to deep aquifer system associated with the area. The area is within the tropical rain forest region of Nigeria characterized by wet and dry seasonal variations, with a mean annual rainfall of $180 \mathrm{~cm}$, mean temperature of $24^{\circ} \mathrm{C}$, and mean humidity of $80 \%$ [19]. The study area is generally characterized by flat and gently undulating topography. Topographic elevations vary from about 50 to $120 \mathrm{~m}$ above sea level in the mainland and 2 to $10 \mathrm{~m}$ in the coastal area (Fig. 2). The area is drained by many perennial streams and rivers such as Ominla, Akeun, Ufara, Okomu, Ofara and others, which form a network of dendritic drainage pattern and empty their waters into the Atlantic Ocean to the south [20].

The mainland of the study area is incised by few motorable roads and several feeder roads and foot paths. These rivers and streams are being fed by several lagoons, ponds, canals, creeks and small streams scattered across the study area. The area is characterized by heavy annual rainfall averaging about 2,000 $\mathrm{mm}$. Rainfall is distributed virtually over all the months of the year with the minima occurring between November and March [19]. Plant type is generally mangrove in the costal part of the study area, typical of swamp forest, while the mainland area is characterized by oil palm, rubber plantation and other broadleaved species, typical of rainforest vegetation. The different ethnic groups that live in the area are the Egbados, Ikales, Ilajes and Ijaws. They live in hamlets, villages and towns which are closely separated from each other although mostly connected by fairly-good to poor roads [20].

The eastern Dahomey basin, geologically where the study area located (Fig. 3), as beginning with the Abeokuta Group [21], made up of three Formations from oldest to the youngest namely; the Ise, Afowo and Araromi Formations (Table 1). The Ise Formation unconformably overlies the basement complex of southwestern Nigeria and consists of conglomerates and grits at base and in turn overlain by coarse-to-medium grained sands with interbedded Kaolinite. The conglomerates are unimbricated and at some locations ironstones occur [22]. The age is Neocomian to Albian. 
Overlying the Ise Formation is the Afowo Formation, which composed of coarse to medium grained sandstones with variable but thick interbedded shales, siltstones and claystones. The sandy facies are tar-bearing while the shales are organic-rich [23]. The lower part of this Formation is transitional with mixed brackish to marginal horizons that alternate with well sorted, sub-rounded sands indicating a littoral or estuarine near-shore environment of deposition.

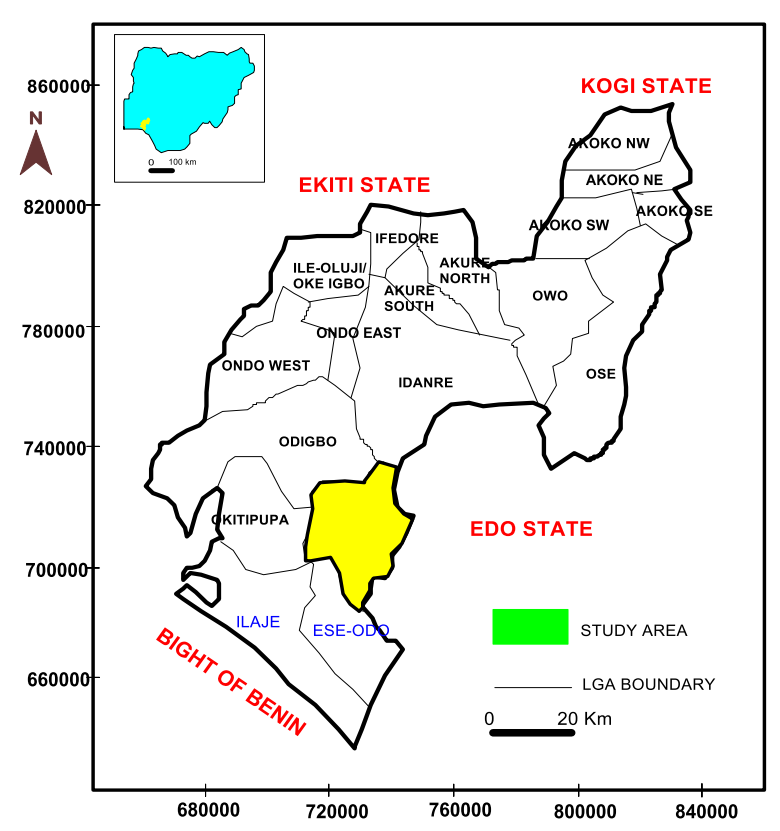

Fig. 1. Location map of the study area

Using palynological assemblage, Billman [24] assigned a Turonian age to the lower part of this Formation, while the upper part ranges into the Maastritchian. Araromi Formation overlies the Afowo Formation (Fig. 3) and has been described as the youngest cretaceous sediment in the eastern Dahomey basin [25]. It is composed of fine to medium grained sandstone at the base, overlain by shales, siltstone with interbedded limestone, marl and lignite. This Formation is highly fossiliferous containing abundant planktonic foraminifera, Ostracods, pollen and spores. Omatsola and Adegoke [25] assigned a maastritchian to palaeocence age to this Formation based on faunal content. The Ewekoro Formation overlies the Araromi Formation in the eastern Dahomey basin. It is an extensive limestone body, which is traceable over a distance of about $320 \mathrm{~km}$ from Ghana in the west, towards the eastern margin of the Dahomey basin in Nigeria [26]. Elueze and Nton [27], has reported that the limestone is of shallow marine origin owing to abundance of coralline algae, gastropods, pelecypods, echinoid fragments and other skeletal debris. It is Palaeocene in age. Overlying the Ewekoro Formation is the Akinbo Formation, which is made up of shale and clayey sequence [28]. The claystones are concretionary and are predominantly Kaolinite [27]. The base of the Formation is defined by the presence of glauconitic band with lenses of limestone [22], [28]. The Formation is Palaeocene to Eocene in age. The Oshosun Formation overlies the Akinbo Formation (Fig. 3) and consists of greenish grey or beige clay and shale with interbeds of sandstones. The shale is thickly laminated and glauconitic. According to Okosun
[30], the basal beds consist of any of the following facies; sandstones, mudstones, claystones, clay-shale or shale. This Formation is phosphate-bearing [22], [26]. The Ilaro Formation overlies conformably the Oshosun Formation and consists of massive yellowish poorly, consolidated, crossbedded sand stones.

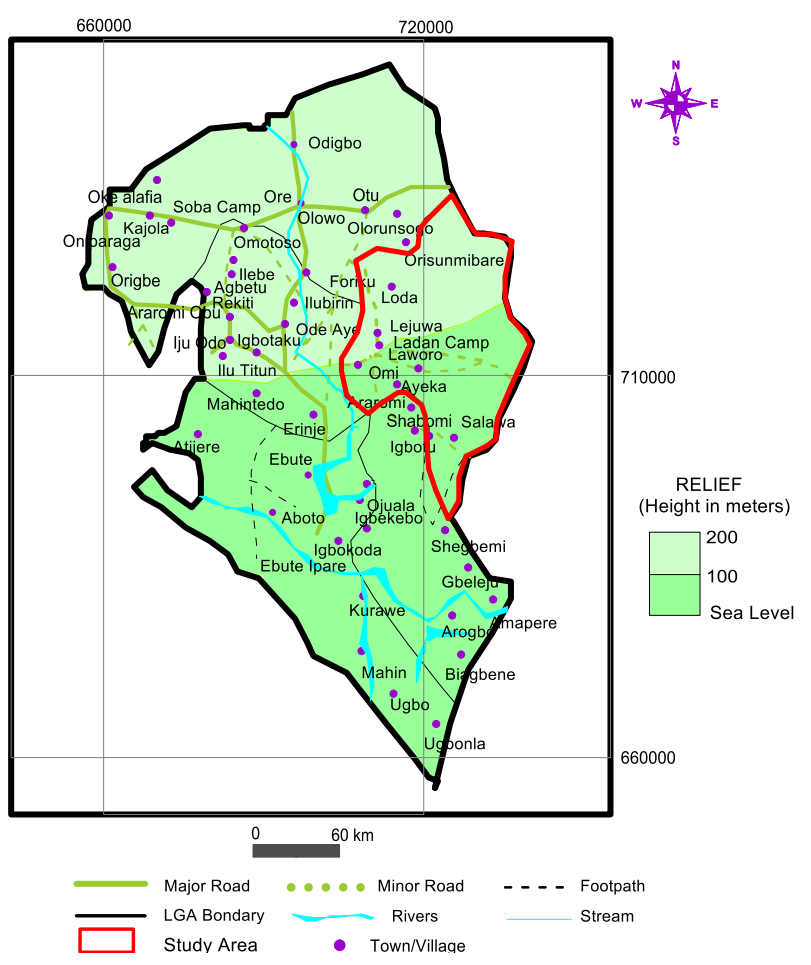

Fig. 2. Surface Relief map of the study area

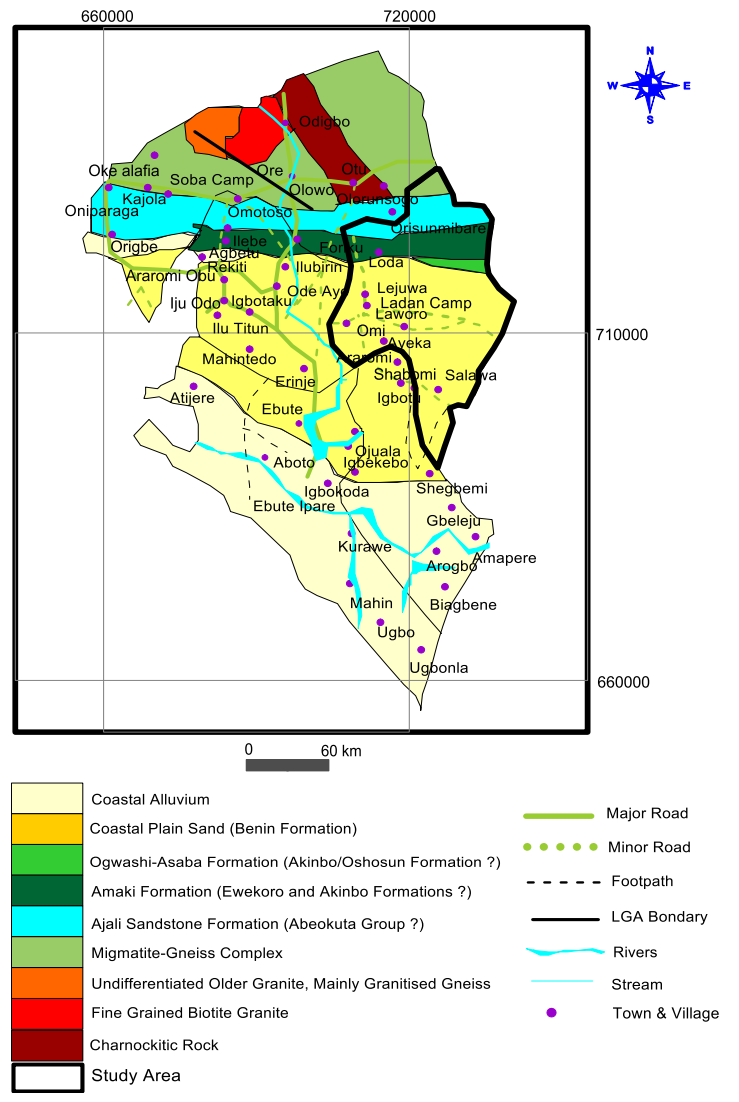

Fig. 3. Geology map of Southern Ondo State, showing the predominant 
Benin Formation in the Study Area

The youngest stratigraphic sequence in the eastern Dahomey basin is the Benin Formation (Fig. 3). It is also known as the coastal plain sands [26] and consists of poorly sorted sands with lenses of clays. The sands are in parts cross bedded and show transitional to continental characteristics. The age is from Oligocene to recent.

TABLE 1: SUMMARY OF THE GEOLOGY OF THE STUDY AREA [29]

\begin{tabular}{|c|c|c|c|}
\hline Group & Formation & Lithology & Age \\
\hline & Benin & $\begin{array}{l}\text { Poorly sorted sands } \\
\text { with lenses of clay }\end{array}$ & Oligocene-recent \\
\hline & Ilaro & $\begin{array}{l}\text { Massive, yellowish } \\
\text { poorly consolidated } \\
\text { cross-bedded } \\
\text { sandstones }\end{array}$ & Eocene \\
\hline & Oshosun & $\begin{array}{l}\text { Greenish or beige clay } \\
\text { with interbeds of } \\
\text { sandstones }\end{array}$ & Eocene \\
\hline & Akinbo & $\begin{array}{l}\text { Shale and clayey } \\
\text { sequence }\end{array}$ & $\begin{array}{l}\text { Paleocene- } \\
\text { Eocene }\end{array}$ \\
\hline & Ewekoro & $\begin{array}{l}\text { Limestone with } \\
\text { presence of coralline } \\
\text { algae, gastropods, } \\
\text { pelecypods, echinoids } \\
\text { fossils }\end{array}$ & Paleocene \\
\hline Abeokuta & Araromi & $\begin{array}{l}\text { Shales, siltstone with } \\
\text { interbedded limestone, } \\
\text { marl and lignite } \\
\text { Medium-fine grained } \\
\text { sandstone }\end{array}$ & $\begin{array}{l}\text { Maastritchian } \\
\text { Paleocene }\end{array}$ \\
\hline & Afowo & $\begin{array}{l}\text { Coarse-medium } \\
\text { grained sandstone; } \\
\text { interbedding of shales, } \\
\text { siltstones and } \\
\text { claystones }\end{array}$ & $\begin{array}{l}\text { Turonian } \\
\text { Maastritchian }\end{array}$ \\
\hline & Ise & $\begin{array}{l}\text { Coarse-medium } \\
\text { grained sands }\end{array}$ & $\begin{array}{l}\text { Neocomian- } \\
\text { Albian }\end{array}$ \\
\hline & & $\begin{array}{l}\text { Conglomerates and } \\
\text { grits }\end{array}$ & \\
\hline \multicolumn{3}{|c|}{ Basement Complex } & Precambrian \\
\hline
\end{tabular}

\section{MATERIAL AND METHODS}

Adopted approaches used in this study involved the geological, geophysical and geotechnical investigations. These were followed by desktop and reconnaissance studies for the purpose of site identification by confirming and updating of existing information. Geologic study involves location of outcrops identification, description of featured characteristics, collection and labeling and of samples. Geotechnical investigation involves collection of disturbed representative samples from trial pit. Properties tested include the particle size distribution, Atterberg limits, strength, and consolidation. The 1-D vertical electrical resistivity sounding data (VES) was obtained using the Schlumberger electrode array [30] with the Allied Ohmega Resistivity meter. Two traverses of $120 \mathrm{~m}$ each were established within the premises of the study area, which runs W-E respectively (Fig. 4). Six vertical electrical soundings (VES) were occupied along the traverses with electrode spacing $(A B / 2)$ ranging from 1 to $750 \mathrm{~m}$ were conducted within the study area using PASI resistivity meter. The location of each of the sounding station was recorded with the aid of GPS Garmin-12-channel. The apparent resistivity measurement at each station was plotted on bi-logarithmic graph sheets. The curves were inspected visually to determine the number and nature of the layering. Partial curve matching was carried out for the quantitative interpretation of the curves. The results of the curve matching (layer resistivities and thicknesses) were fed into the computer as a starting model in an iterative forward modelling technique 1-D inversion program. From the interpretation results (layer resistivities and thicknesses), two geoelectric sections were produced.

The trial pit was conducted by digging a shallow pit and physical inspection of the subsoil (Fig. 5). Seven samples were collected at different depths and put into a plastic bag and transported to the soil laboratory, the soil was air dried and lightly crushed into smaller pieces for classification, strength and specialized tests according to the British Standard [30]. The CPT data used in this report are those acquired by an apex angle of $60^{\circ}$ and a base area of $10 \mathrm{~cm} 2$ friction cone penetrometers. In these tests the total cone tip resistance (qc) and sleeve friction (fs) were recorded and no pore water pressures were measured. The study was carried out for about a week in September 2019. There are three main aims of this investigation: to locate very dense bearing layers with qc $>50 \mathrm{~kg} / \mathrm{cm} 2$ at two selected locations; to identify and classify the type of soil on each location; and to estimate the allowable bearing capacity of each bearing layer on each location. Using the soil classification developed by [31], the friction ratio $\mathrm{Rf} \%$ or the ratio between side friction and cone friction (fc/qc) derived from the CPT was used in soil profiling.

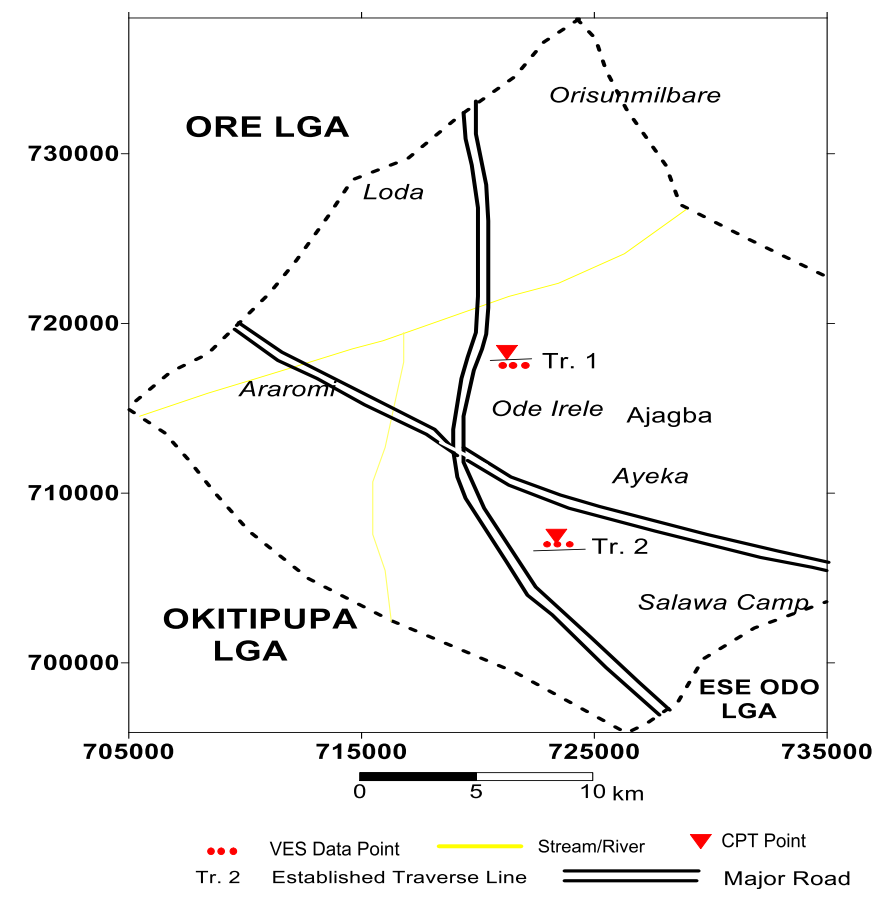

Fig. 4. Data Acquisition Map

The layer sequences were interpreted from the variation of the values of the cone resistance with depth. The allowable bearing pressure of the soil layers on each location was calculated using Meyerhof [32] and Schmertmann [33] direct method equations for estimating ultimate bearing capacity ( $\mathrm{qult}_{\mathrm{ul}}$ ) from cone resistance for 
square and strip footings, using (1) to (5):

$$
q_{u l t}=q_{c}\left(\frac{B}{12.2}\right)\left(1+\frac{D_{f}}{B}\right)
$$

$\mathrm{q}_{\mathrm{c}}=$ cone resistance value

$\mathrm{D}_{\mathrm{f}}=$ Depth of footing

$\mathrm{B}=$ Width of foundation

Factor of safety at least 3 is recommended by [32] to obtain the allowable bearing pressure.

For cohensionless soils:

Strip $\quad q_{u l t}=28-0.0052\left(300-q_{c}\right)^{1.5}$

Square $q_{u l t}=48-0.0052\left(300-q_{c}\right)^{1.5}$

For clay:

Strip $\quad q_{\text {ult }}=2+0.28 q_{c}$

Square $q_{\text {ult }}=5+0.34 q_{c}$

All samples obtained in the field were carefully preserved and subjected to more detailed visual inspection and descriptions at the laboratory. Thereafter, representative samples were selected from each stratum for laboratory analysis in accordance with relevant geotechnical engineering standards including BS 1377 [30].The disturbed soil samples were appropriately subjected to the following laboratory classification tests: natural moisture content; Atterberg limits (liquid and plastic limits); grain size analysis; and unconsolidated undrained triaxial tests at different cell pressures. Sieve analysis of cohesive soils were done by soaking oven-dried samples in water overnight and washing through sieve No. 200 (75 microns opening) while remnants retained on sieve No. 200 were oven-dried and sieved mechanically. Materials finer than sieve number 200 were analyzed using the hydrometer method based on Stoke's law.

Total consolidation settlement (s) has been computed for foundation breadth (B) between $0.5-3.0 \mathrm{~m}$, subjected to allowable bearing capacity of $100 \mathrm{kN} / \mathrm{m}^{2}$. The induced vertical stress $(\Delta \sigma)$ at the center of the consolidating layer has been used in computing $\mathrm{s}$. The consolidation settlement has been computed from the expression below [34] in (6).

$$
s=m_{v} H \Delta \sigma^{\prime}
$$

$m_{v}=$ coefficient of volume compressibility

$H=$ thickness of compressible layer

$\Delta \sigma^{\prime}=$ average increase in effective pressure

An $\mathrm{m}_{\mathrm{v}}$ value of $0.125 \mathrm{~m}^{2} / \mathrm{KN}$, which corresponds to the adopted net allowable bearing capacity was used in the settlement analysis and also corresponds to stiff clay in the range of $\left(0.25-0.125 \mathrm{~m}^{2} / \mathrm{KN}\right)$.

\section{RESULTS AND DISCUSSION}

\section{A. Electrical Resistivity}

The geoelectric sections along Traverse 1 in Ode Irele is shown in Fig. 6, and identified maximum of six geoelectric/geologic subsurface layers comprising the topsoil (red sand), weathered layer (made up of coastal sand/white sand), clayey sand (which is the major aquitard in the area), intermediate sand aquifer unit. The topsoil is characterized by resistivity ranging from $112-797$ ohm-m with thickness of $1.7-2.6 \mathrm{~m}$. The weathered layer has resistivity varying from 822 - 4889 ohm-m, with thickness of $34.2-38.3 \mathrm{~m}$. The clay sand underlying the weathered layer has resistivity varying from 425 - 622 ohm-m and thickness of 114.7 to $138.8 \mathrm{~m}$. The intermediate sand aquiferous is characterized with resistivity in between 4118 and $5140 \mathrm{ohm}-\mathrm{m}$, and depth range to this geologic unit is in between 150.7 - $178.8 \mathrm{~m}$. The overburden thickness along this traverse is thick enough to dissipate effectively the structural load to the underlying soil units. However the coastal sand layer has moderately high resistivity at shallow depth (795 - $936 \mathrm{ohm}-\mathrm{m})$ to sustain foundation load with thickness of $1.9-3.4 \mathrm{~m}$. The presence of groundwater in the soil pores has a very significant impact on the engineering behavior or characteristics of the soil, and very important where deep excavation are to be carried out. The groundwater level along this traverse measured during the CPT survey under VES 1 records value of $0.5 \mathrm{~m}$, which is believed to be connate water trapped during sedimentation/lithification process.

The geoelectric section along Traverse 2 in Ajagba (Fig. 7) showed four distinct subsurface layering, comprising the topsoil (red sand), sand, clayey sand, and clayey material. The topsoil is made of tropical red sand with resistivity varying from $455-696 \mathrm{ohm}-\mathrm{m}$ and thickness of $1.1-1.4 \mathrm{~m}$. The sand material underlying the red sand is characterized with resistivity values varying from 1220 - $3325 \mathrm{ohm}-\mathrm{m}$, and thickness variation of $29.1-42.6 \mathrm{~m}$. The clayey sand aquitard layer overlain the clay/shale material and has resistivity ranging from $715-860 \mathrm{ohm}-\mathrm{m}$ and thickness of $80.1-110.1 \mathrm{~m}$. The depth to clay/shale which form the basement soil/rock in the area, varies in between 110.6 and $153.9 \mathrm{~m}$. The existing borehole under VES 4 records groundwater level of $17.5 \mathrm{~m}$. This depth is far below the targeted (maximum) foundation depth and width of $10 \mathrm{~m}$ for shallow foundation design in the area. This implies that the groundwater level may not or seriously affect the bases of the foundation footing along this area [4]. Hence the topsoil (tropical red sand) and coastal white sand are competent (judging from the layers resistivity and thickness) to harbor the foundation structure along this traverse.

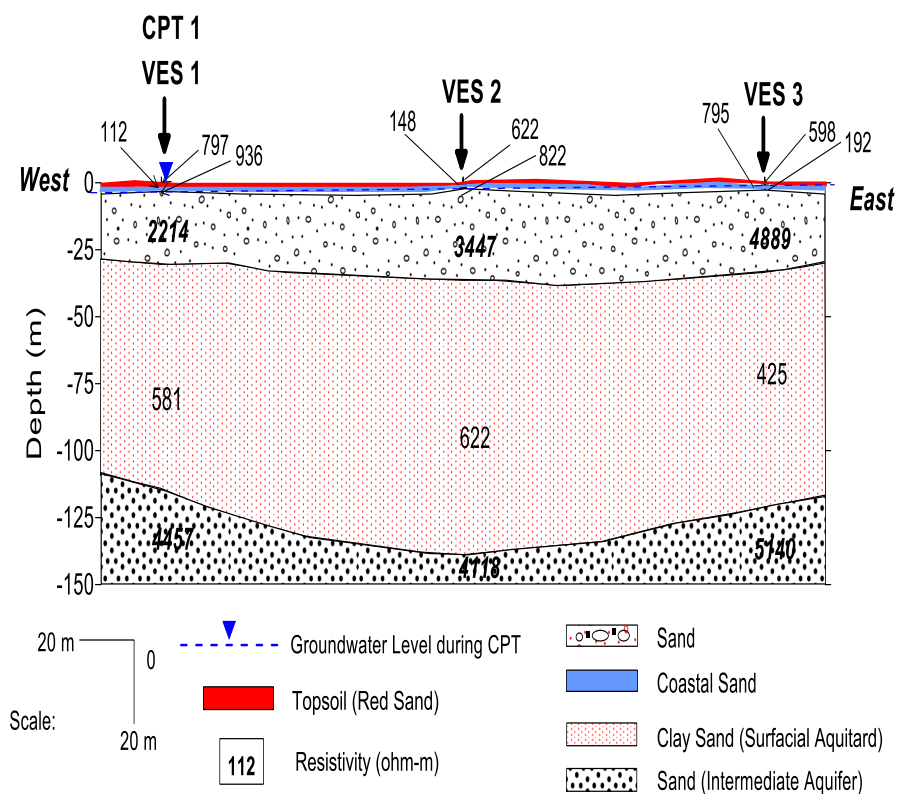

Fig. 6. Geoelectric Section along Traverse 1 in Ode Irele 


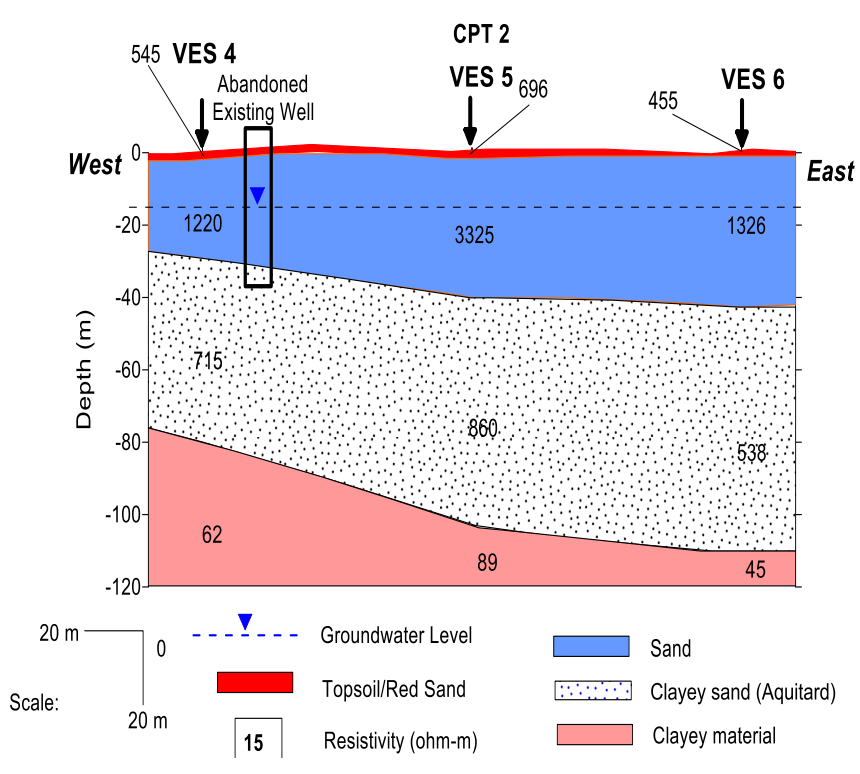

Fig. 7. Geoelectric Section along Traverse 2 in Ajagba

\section{B. Geotechnical Investigation}

Tables 1 and 2 show the summary of the geotechnical results. The $\%$ sand varies in between $40.3-87.3$, silt varies from $4.5-35.6 \%$, and clay ranges from $8.2-35.3 \%$. Generally the soil is dominated by sand and silt. The average clay content in the soil is less than $20 \%$ which falls within $35 \%$ recommended for subsoil material that are good for construction. The specific gravity of the soil recorded values in the range of $2.64-2.68$. Consequently it is expected that such soil will undergo immediate/elastic settlement than consolidation settlement, since most silty (except plastic silt) and granular soil undergo total settlement even shortly after construction. The analyzed soil samples at both locations shows liquid limits of $21.1-36.6$ $\%$ (within recommended $50 \%$ ), plastic limits of $19.5-20.8$ $\%$ (within recommended $30 \%$ ), plasticity index of $7.0-$ $14.5 \%$ (within recommended $20 \%$ ), and shrinkage limits of $0.7-7.9 \%$ (excellent soil quality). Generally, the lower the linear shrinkage, the lesser the tendency for the soil to shrink when desiccated [35]. The natural moisture content ranges from $11.8-16.9 \%$ which is moderately low. However location 2 shows better geotechnical properties than location 1 , even though they show some overlap in their geotechnical properties. All the soil samples fall within the FMWH [36] recommended standard for foundation material. Hence, the soil can be adjoin as a good foundation soil.

The results of the CPT and laboratory analysis of samples collected during trial test/soil examination is presented in Tables 2 and 3. The result shows increase in cone resistance and sleeve resistance with depth, ranging from $15-70$ $\mathrm{kg} / \mathrm{cm}^{2}$ and $25-105 \mathrm{~kg} / \mathrm{cm}^{2}$ at CPT 1 , and $25-80 \mathrm{~kg} / \mathrm{cm}^{2}$ and $40-125 \mathrm{~kg} / \mathrm{cm}^{2}$ at CPT 2 respectively. The friction ratio ranges from $1.05-1.67$ (CPT 1) and $1.08-1.67$ (CPT 2). The Robertson [37] soil chart classification shows wide variation of zones 5 to 7 corresponding to clayey silt to silty clay, sandy silt to silty clay, and silty sand to sandy silt respectively (Fig. 8). The plots of cone resistance and sleeve resistance against depth (Fig. 10) showed a geological succession of clayey silt to silty clay $(0-0.2 \mathrm{~m})$, sandy silt to clayey silt $(0.2-0.8 \mathrm{~m})$, silty sand to sandy silt $(0.8-2.0 \mathrm{~m})$ at CPT 1 and two geologic sequence in CPT 2 as sand silt to clayey silt $(0-0.4 \mathrm{~m})$ and silty sand to sandy silt $(0.4-1.0$ $\mathrm{m})$. Consequently, depth of $0.8 \mathrm{~m}$ would be appropriate as founding depth for design and construction of shallow foundation and bases in the area.

\section{Bearing Capacity Determination}

The ultimate and allowable bearing capacity estimated from the cone resistance is presented in Table 4. The calculated bearing capacities could be used in determining the foundation type for structures [38]. The allowable bearing of the soil varies between 37 to $184 \mathrm{KN} / \mathrm{m}^{2}$ for CPT 1 , and $61-196 \mathrm{KN} / \mathrm{m}^{2}$ for CPT 2. Consequently an average allowable bearing capacity of $150 \mathrm{KN} / \mathrm{m}^{2}$ (ultimate bearing capacity of $450 \mathrm{KN} / \mathrm{m}^{2}$ ) would be appropriate for design of shallow foundation in the area, at a depth not less than $1.6 \mathrm{~m}$ in location 1 (Ode Irele) and $0.8 \mathrm{~m}$ at location 2 (Ajagba). Settlement and bearing capacity are the major factors that govern foundation design. The commonly accepted basis of design is that the total settlement of a footing should be restricted to about $25 \mathrm{~mm} \mathrm{[39]-[40]} \mathrm{as} \mathrm{by} \mathrm{so} \mathrm{doing} \mathrm{the}$ differential settlement between adjacent footings is confined within limits that can be tolerated by a structure. The settlement analysis for foundation width of $0.5 \mathrm{~m}$ at three depth levels of $1 \mathrm{~m}, 2 \mathrm{~m}$ and $3 \mathrm{~m}$ produces relative high values (greater than $25 \mathrm{~mm}$ but less than $50 \mathrm{~mm}$ ) settlement values. But foundation width of $1.5-3 \mathrm{~m}$ produces settlement less than $25 \mathrm{~mm}$ (Table 5). Although according to [32], [33] total settlement limits of $60 \mathrm{~mm}$ (clay) and $50 \mathrm{~mm}$ (granular soil) are still tolerable.

\section{Settlement}

Therefore foundation width not less than $0.6 \mathrm{~m}$ for depth not less than $2 \mathrm{~m}$ is therefore recommended. This foundation width would produce minimum bearing settlement less than $25 \mathrm{~mm}$. The calculation of bearing capacities for strip and square foundation is shown in Table 6. For strip foundation, the appropriate (recommended) ultimate bearing and allowable bearing capacity for depth levels of $0.6-1.2 \mathrm{~m}$ vary from $1486-1842 \mathrm{KN} / \mathrm{m}^{2}$ and $495-614 \mathrm{KN} / \mathrm{m}^{2}$, while square footing varies in between $2056-2489 \mathrm{KN} / \mathrm{m}^{2}$ and $685-830 \mathrm{KN} / \mathrm{m}^{2}$ respectively.

\section{CONCLUSION}

The subsoil layers comprised the topsoil (red sand), weathered layer (made up of coastal sand/white sand), clayey sand (which is the major aquitard in the area), intermediate sand aquifer unit. However the coastal sand layer has moderately high resistivity at shallow depth to sustain foundation load with thickness of greater than $2 \mathrm{~m}$. The existing borehole records groundwater level of $17.5 \mathrm{~m}$ that may not or seriously affect the bases of the foundation footing along this area. All the soil samples fall within the FMWH recommended standard for foundation material. Hence, the soil can be adjoin as a good foundation soil. Consequently an average allowable bearing capacity of 150 $\mathrm{KN} / \mathrm{m}^{2}$ would be appropriate for design of shallow foundation in the area, at a depth not less than $1.6 \mathrm{~m}$ in location 1 (Ode Irele) and $0.8 \mathrm{~m}$ at location 2 (Ajagba). 
TABLE 2: GEOTECHNICAL/ENGINEERING PROPERTIES OF SOIL IN LOCATION 1

\begin{tabular}{|c|c|c|c|c|c|c|c|c|c|c|c|c|c|}
\hline $\begin{array}{l}\text { Depth } \\
\text { (m) }\end{array}$ & $\begin{array}{l}\text { Cone } \\
\text { Resistance }\end{array}$ & $\begin{array}{l}\text { Sleeve } \\
\text { Resistance }\end{array}$ & $\begin{array}{l}\text { Friction } \\
\text { Ratio }\end{array}$ & $\begin{array}{l}\text { L.L } \\
(\%)\end{array}$ & $\begin{array}{l}\text { P.L } \\
(\%)\end{array}$ & $\begin{array}{l}\text { P.I } \\
(\%)\end{array}$ & $\begin{array}{l}\text { S.L } \\
(\%)\end{array}$ & $\begin{array}{l}\text { M.C } \\
(\%)\end{array}$ & $\begin{array}{l}\% \\
\text { Gravel }\end{array}$ & $\begin{array}{l}\% \\
\text { Sand }\end{array}$ & $\begin{array}{l}\% \\
\text { Silt }\end{array}$ & $\begin{array}{l}\% \\
\text { Clay }\end{array}$ & S.G \\
\hline 0.2 & 15 & 25 & 1.67 & 36.6 & 22.1 & 14.50 & 7.9 & 11.8 & - & 46.5 & 19.4 & 34.1 & 2.64 \\
\hline 0.4 & 20 & 30 & 1.50 & & & & & & & & & & \\
\hline 0.6 & 30 & 35 & 1.17 & 31.0 & 19.5 & 11.50 & 7.2 & 12.5 & - & 45.4 & 19.3 & 35.3 & 2.66 \\
\hline 0.8 & 35 & 40 & 1.14 & & & & & & & & & & \\
\hline 1.0 & 40 & 42 & 1.05 & & & & & & & & & & \\
\hline 1.2 & 48 & 60 & 1.25 & 30.7 & 20.5 & 10.2 & 7.0 & 15.8 & - & 40.3 & 35.6 & 24.1 & 2.67 \\
\hline 1.4 & 50 & 65 & 1.30 & & & & & & & & & & \\
\hline 1.6 & 75 & 90 & 1.20 & & & & & & & & & & \\
\hline 1.8 & 70 & 105 & 1.50 & 31.3 & 20.8 & 10.5 & 7.1 & 16.9 & - & 44.8 & 30.6 & 24.6 & 2.67 \\
\hline
\end{tabular}

TABLE 3: GEOTECHNICAL/ENGINEERING PROPERTIES OF SOIL IN LOCATION 2

\begin{tabular}{llllllllllllll}
\hline $\begin{array}{l}\text { Depth } \\
(\mathbf{m})\end{array}$ & $\begin{array}{l}\text { Cone } \\
\text { Resistance }\end{array}$ & $\begin{array}{l}\text { Sleeve } \\
\text { Resistance }\end{array}$ & $\begin{array}{l}\text { Friction } \\
\text { Ratio }\end{array}$ & $\begin{array}{l}\text { L.L } \\
\mathbf{( \% )}\end{array}$ & $\begin{array}{l}\text { P.L } \\
\mathbf{( \% )}\end{array}$ & $\begin{array}{l}\text { P.I } \\
\mathbf{( \% )}\end{array}$ & $\begin{array}{l}\text { S.L } \\
\mathbf{( \% )}\end{array}$ & $\begin{array}{l}\text { M.C } \\
(\mathbf{\%})\end{array}$ & $\begin{array}{l}\text { \% } \\
\text { Gravel }\end{array}$ & $\begin{array}{l}\text { \% } \\
\text { Sand }\end{array}$ & $\begin{array}{l}\text { \% } \\
\text { Silt }\end{array}$ & $\begin{array}{l}\text { \% } \\
\text { Clay }\end{array}$ & S.G \\
\hline 0.2 & 25 & 40 & 1.60 & 28.4 & 21.2 & 7.25 & 2.9 & 13.9 & - & 74.2 & 12.2 & 13.6 & 2.68 \\
0.4 & 30 & 50 & 1.67 & & & & & & & & & & \\
0.6 & 65 & 70 & 1.08 & 27.4 & 20.4 & 7.00 & 2.9 & 13.5 & - & 75.9 & 10.1 & 14.0 & 2.68 \\
0.8 & 68 & 75 & 1.10 & & & & & & & & & & \\
1.0 & 80 & 125 & 1.56 & 21.1 & NP & - & 0.7 & 13.1 & - & 87.3 & 4.5 & 8.2 & 2.68 \\
\hline
\end{tabular}

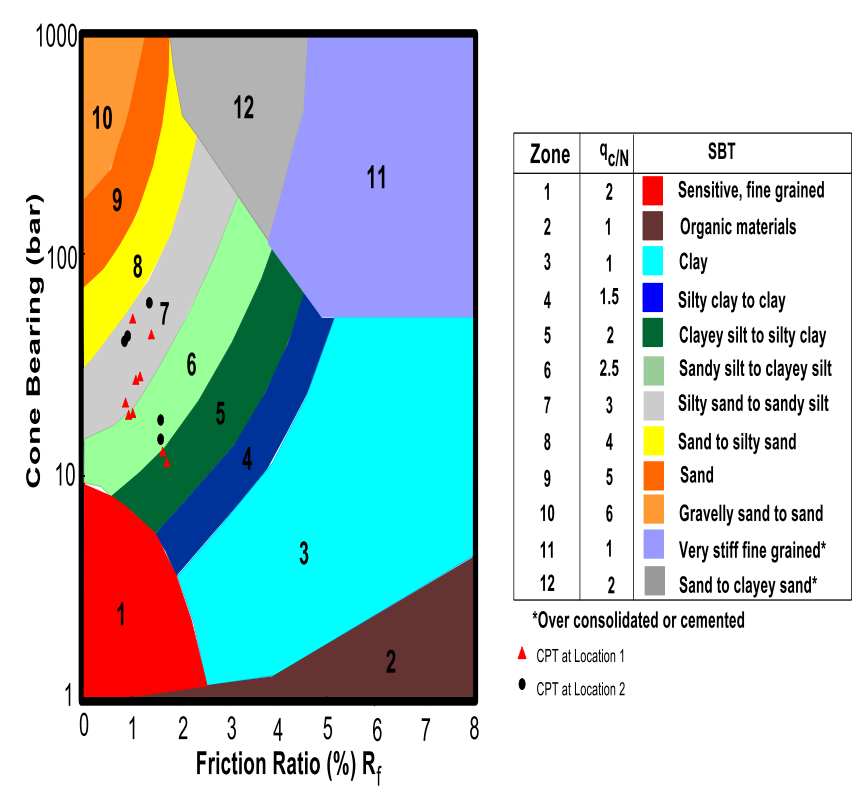

Fig. 8. Robertson [37] Soil Classification Chart and Description of Different zones for soil in the study area

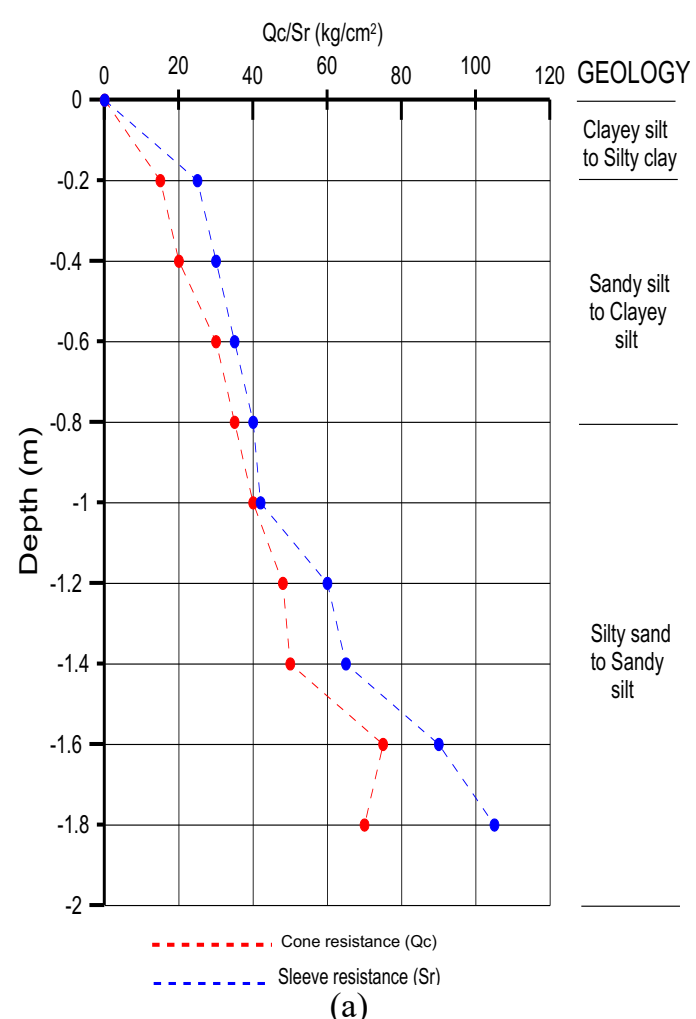

(a) 


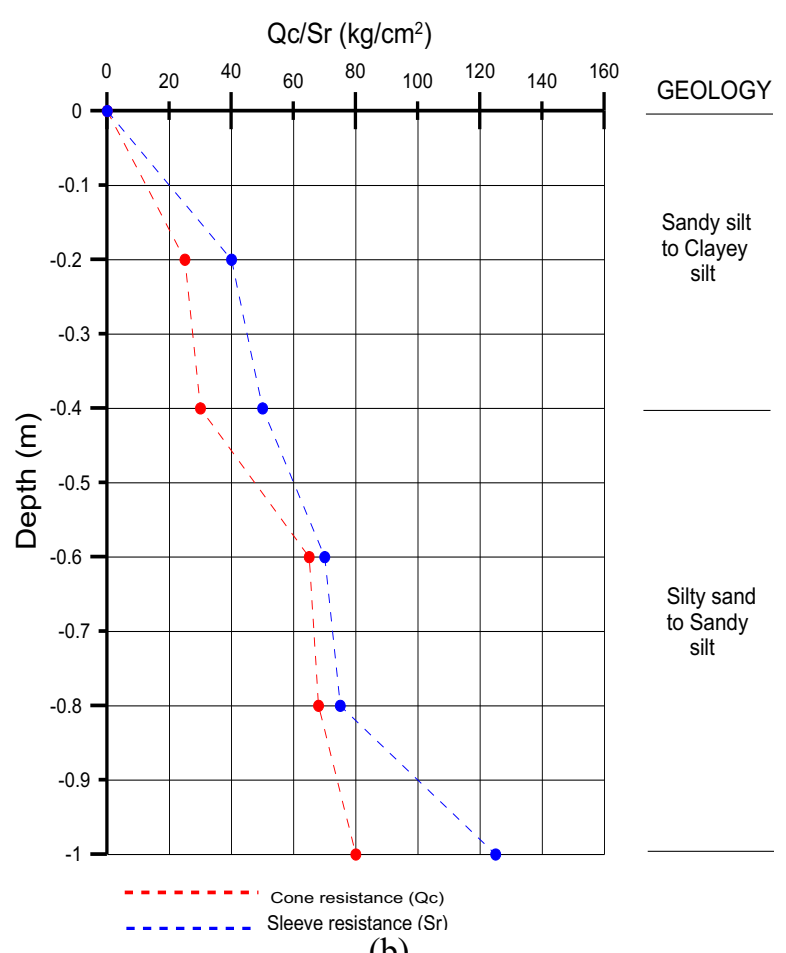

(b)

Fig. 9. Plots cone resistance and sleeve resistance against depth at location 1 and 2 corresponding to (a) Ode Irele (b) Ajagba

TABLE 4: BEARING CAPACITIES ESTIMATED FROM THE CPT VALUES FOR BOTH LOCALITIES

\begin{tabular}{|c|c|c|c|c|}
\hline \multirow{2}{*}{$\begin{array}{c}\text { Depth } \\
\text { (m) }\end{array}$} & \multicolumn{2}{|c|}{ CPT 1} & \multicolumn{2}{|c|}{ CPT 2} \\
\hline & $\begin{array}{r}q_{\text {allowable }} \\
\left(\mathrm{KN} / \mathrm{m}^{2}\right)\end{array}$ & $\begin{array}{l}q_{\text {ultimate }} \\
\left(\mathrm{KN} / \mathrm{m}^{2}\right)\end{array}$ & $\begin{array}{r}q_{\text {allowable }} \\
\left(\mathrm{KN} / \mathrm{m}^{2}\right)\end{array}$ & $\begin{array}{l}q_{\text {ultimate }} \\
\left(\mathrm{KN} / \mathrm{m}^{2}\right)\end{array}$ \\
\hline 0.2 & 37 & 110 & 61 & 184 \\
\hline 0.4 & 49 & 147 & 74 & 221 \\
\hline 0.6 & 74 & 221 & 159 & 478 \\
\hline 0.8 & 86 & 257 & 167 & 500 \\
\hline 1.0 & 98 & 294 & 196 & 588 \\
\hline 1.2 & 118 & 353 & - & - \\
\hline 1.4 & 123 & 368 & - & - \\
\hline 1.6 & 184 & 551 & & \\
\hline 1.8 & 172 & 515 & & \\
\hline
\end{tabular}

TABLE 5: SETTLEMENT VARIATION AT DIFFERENT DEPTHS AND FOUNDATION WIDTH

\begin{tabular}{llll}
\hline $\begin{array}{l}\text { Foundation width } \\
(\mathrm{m})\end{array}$ & \multicolumn{3}{l}{ Settlement $(\mathrm{mm})$ at Depth Level $(\mathrm{m})$} \\
\cline { 2 - 4 } & $1 \mathrm{~m}$ & $2 \mathrm{~m}$ & $3 \mathrm{~m}$ \\
\hline 0.2 & 44.92 & 43.87 & 50.85 \\
0.6 & 25.32 & 22.51 & 33.32 \\
1.5 & 20.94 & 21.36 & 29.47 \\
2.0 & 15.29 & 15.90 & 23.88 \\
3.0 & 9.96 & 10.72 & 18.73 \\
\hline
\end{tabular}

TABLE 6: BEARING CAPACITIES FOR STRIP AND SQUARE SHALLOW FOUNDATION DESIGN

\begin{tabular}{ccccc}
\hline Depth $(\mathrm{m})$ & Strip & Square & Strip & Square \\
\cline { 2 - 5 } & $\begin{array}{c}q_{\text {ultimate }} \\
\left(\mathrm{KN} / \mathrm{m}^{2}\right)\end{array}$ & $\begin{array}{c}q_{\text {ultimate }} \\
\left(\mathrm{KN} / \mathrm{m}^{2}\right)\end{array}$ & $\begin{array}{c}q_{\text {allowable }} \\
\left(\mathrm{KN} / \mathrm{m}^{2}\right)\end{array}$ & $\begin{array}{c}q_{\text {allowable }} \\
\left(\mathrm{KN} / \mathrm{m}^{2}\right)\end{array}$ \\
\hline 0.6 & 1486 & 2056 & 495 & 685 \\
1.2 & 1842 & 2489 & 614 & 830 \\
\hline
\end{tabular}

Therefore foundation width not less than $0.6 \mathrm{~m}$ is therefore recommended. This foundation width would produce minimum bearing settlement less than $25 \mathrm{~mm}$. The appropriate (recommended) ultimate bearing and allowable bearing capacity for strip and square footings at depth levels of $0.6-1.2 \mathrm{~m}$ vary from $1486-1842 \mathrm{KN} / \mathrm{m} 2$ and $495-614$ $\mathrm{KN} / \mathrm{m} 2$, while square footing varies in between $2056-2489$ $\mathrm{KN} / \mathrm{m} 2$ and $685-830 \mathrm{KN} / \mathrm{m} 2$ respectively.

\section{ACKNOWLEDGMENT}

Special appreciation to TETFund, Nigeria through Centre for Research and Development of Rufus Giwa Polytechnic, Owo, Ondo State, Nigeria for providing the fund for this research work.

\section{REFERENCES}

[1] A.A. Fakere, G. Fadairo, and R.A. Fakere, "Assessment of Building Collapse in Nigeria: A Case of Naval Building, Abuja, Nigeria," International Journal of Engineering and Technology, 2(4), 2012, pp. 584-592.

[2] R.B. Ibrahim, "Monumental Effects of Building Collapse in Nigerian cities: The case of Lagos Island, Nigeria," Basic Research Journal of Engineering Innovation, 1(2), 2013, pp. 26- 31.

[3] B.M. Das, Principles of Foundation Engineering: 5th Edition. Brooks/Coe Publishing Co., California, 2004.

[4] J.E. Bowles, Foundation Analysis and Design: McGraw-Hill Book Company, Singapore, 1998.

[5] V.N.S. Murthy, Principles and Practices of Soil Mechanics and Foundation Engineering: CRC Press, Florida, 2002.

[6] K. Tezaghi, R.B. Peck, Soil Mechanics in Engineering Practice: John Wiley \& Sons, Inc., 2nd edition, New York, 1967, p. 491.

[7] A. Mazlan, "Correlation between Cone Penetration Test and Bearing Capacity for Shallow Foundation," Master's Thesis. Universiti Teknologi Malaysia, 2007.

[8] A.O. Coerts, "Analysis of static cone penetration test data for subsurface modelling: A methodology," $\mathrm{PhD}$ Thesis, Nethernals Geographical Studies, 1996: 263pp

[9] T. Lunne, P.K. Robertson, J.J.M. Powell, Cone Penetration Testing in Geotechnical Practise: Blackie Academic and Professional, London, 1997, 312p

[10] H. Saniee, "New method for determinig bearing capacity of shallow foundation on cohensionless soils," Proceedings of the second international seminar on soils mechanics and foundation engineering of IRAN, Tehran, 1993, pp.133-148.

[11] M.O. Olorunfemi, E.A. Meshida, "Engineering geophysics and its application in Engineering site investigation: Case study from Ile-Ife area," Nig. Eng., 24, 1987, pp. 57-66.

[12] G.V. Palacky, Resistivity characteristics of geologic targets. Electromagnetic Methods Appl., Geophysics, 1, 1987, 1351pp.

[13] G.M. Olayanju, K.A. Mogaji, H.S. Lim, T.S. Ojo, "Foundation integrity assessment using integrated geophysical and geotechnical techniques: case study in crystalline basement complex, southwestern Nigeria," Jour. Geophy. Eng. 14 (3), 2017.

[14] E.A. Ayolabi, A.F. Folorunso, O.E. Jegede, "The Application of 2D Electrical Resistivity Tomography in Geotechnical Investigations of Foundation Defects, Ogudu Estate as a Case Study," Journal of Geology and Mining Research, 3(12), 2012, pp. 142 - 151.

[15] J.O. Coker, "Geophysical and Geotechnical Assessment of Foundation Failure: A Case Study of Library Complex Area, Lagos State Polytechnic, Ikorodu, Lagos, Nigeria," Research Journal in Engineering and Applied Sciences, vol. 3, No 7, 2015.

[16] J.O. Coker, V. Makinde, J.K. Adesodun, A.O. Mustapha, "Integration of Geophysical and Geotechnical Investigation for a Proposed New Lecture Theatre at Federal University of Agriculture, Abeokuta, South Western Nigeria," International Journal of Emerging Trends in Engineering and Development, Issue 3, Vol. 5, 2013, pp. 338-348

[17] W.M. Telford, L.P. Geldart, R.E. Sheriff, Applied Geophysics: Second ed. Cambridge University Press, 1990.

[18] P.V. Sharma, Environmental and Engineering Geophysics: Cambridge University Press, 1997, pp. 173.

[19] M.P. Iloeje, A new Geography of Nigeria: Longman Nigeria, 1981, pp. $26-28$. 
[20] G.O. Omosuyi, "Geophysical and Hydrogeological Investigations of Groundwater Prospects in the Southern Part of Ondo State, Nigeria," Ph.D Thesis, Department of Applied Geophysics, Federal University of Technology, Akure, Nigeria. 2001, 195pp.

[21] G.O. Omosuyi, J.S. Ojo, M.O. Olorunfemi, "Hydrochemical Investigation of Groundwater in Okitipupa area, Ondo State, Southwestern Nigeria," Journal of African Water Resources and Environment (Aquaterra), 1 (2), 2007, pp. 3 - 13.

[22] M.E. Nton, "Sedimentological and Geochemical Studies of Rock Units in the Eastern Dahomey Basin, South Western Nigeria," PhD thesis, University of Ibadan, 2001, 315pp.

[23] E.I. Enu, "Nature and Occurrence of Tarsands in Nigeria: Ako, B.D., Enu, E.I. (Eds) Occurrence, Utilization and Economics of Tarsands. Nigeria Mining and Geosciences Society Publication on Tarsands Workshop, Olabisi Onabanjo University, Ago-Iwoye, 11-16, 1990.

[24] H.G. Billman, "Offshore Stratigraphy and Paleontology of the Dahomey Embayment, West African," NAPE Bulletin, 7 (2), 1992, 121-130.

[25] M.E. Omatsola, O.S. Adegoke, "Tectonic Evolution and Cretaceous Stratigraphy of the Dahomey Basin," Journal of Mining and Geology, 8: 1981 , pp. $30-137$.

[26] H.A. Jones, R.D. Hockey, "The Geology of Part of South-Western Nigeria," Geological Survey Nigeria Bulletin, 31: 1964, 56 - 86.

[27] A.A. Elueze, M.E. Nton, "Organic Geochemical Appraisal of Limestones and Shales in Part of Eastern Dahomey Basin, Southwestern Nigeria," Journal of Mining and Geology, 40(1), 2004, pp. $29-40$.

[28] F.G.A. Ogbe, "Stratigraphy of Strata Exposed in the Ewekoro Quarry, Western Nigeria," In T.J.F. Dessauvagie and Whiteman (Eds) African Geology, University Press, Nigeria, 1972, pp. 305 - 322.

[29] D.H. Griffiths, R.D. Barker, "Two dimensional resistivity imaging and modelling in areas of complex geology," J. Appl Geophys, 29: 1993, 211-226

[30] British Standard Institutions, "Methods of Test for soils for Civil Engineering Purposes B.S 1377": Part 2, 1990. pp 8-200

[31] G. Sanglerat, The penetrometer and soil exploration: Elsevier publishing Co., Amsterdam, 1972.

[32] G.G. Meyerhof, "Bearing capacity and settlement," ASCE, Journal of Geotechnical Engineering, vol. 102, GT3, 1976, pp. 195 - 228.

[33] J.H. Schmertmann, "Guidelines for cone test, performance and design": Federal Highway Administration, Report FHWA-TS-78209, Washington, 1978, $145 \mathrm{p}$.

[34] M.A. Stroud, F.G. Butler, "The standard penetration test and the engineering properties of glacial materials," In: Proceedings of the Symposium of glacial materials, University of Birmingham.1975

[35] G. Jegede, "Effect of soil properties on pavement failure along the F209 highway at Ado-Ekiti, Southwestern Nigeria," Journal of Construction and Building Materials, vol. 14, 2000, pp. 311-315,

[36] Federal Ministry of Works and Housing, "Highway Manual Part 1 Road Design," Federal Ministry of Works and Housing, Lagos, 1972.

[37] P.K. Robertson, "Soil classification using the cone penetration test," Canadian Geotechnical Journal, 27: 1990, pp. 151-158.

[38] A.W. Skempton, "The Bearing Capacity of Clays," Proceedings Building Research Congress, vol. 1, 1951, pp. 180-189.

[39] F.G. Bell, Engineering Geology: Elsevier Ltd., 2007.

[40] J.B. Burland, M.C. Burbidge, "Settlement of foundations on sand and gravel," Proceedings of the Institution of Civil Engineers, Part 1, 1985, pp. 1325-1381.

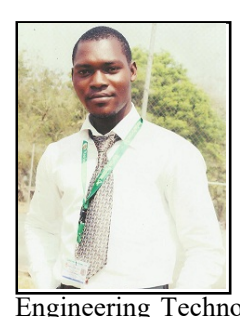

Olumuyiwa O. Falowo was born in Ondo State Nigeria, and holds Bachelor of Science degree in Geology in 2006; Master of Technology in Exploration Geophysics in 2012; Master of Philosophy in Hydrogeology in 2015; and Doctor of Philosophy in Engineering Geology and Geotechnics in 2018.

$\mathrm{He}$ is presently a Lecturer in the Department of Civil Engineering Technology, Faculty of Technology, Rufus Giwa Polytechnic Owo Nigeria. Dr. O.O. Falowo belongs to so many professional bodies such as SEG, EAGE, NMGS, NAH, NAEGE, etc. 